[Agr. Biol. Chem., Vol. 25, No. 5, p. 358 361, 1961]

\title{
Substrate Specificity and Some Properties of Crystalline Mold Maltase
}

\author{
By Shiro Sugawara, Yukihiko Nakamura and Tokuji Shimomura \\ Department of Agricultural Chemistry, University of Hokkaido, Sapporo \\ Received December 8, 1960
}

\begin{abstract}
The substrate specificity of crystalline mold maltase was investigated.
The enzyme acts upon various $a$-heteroglucosides or saccharides. Aryl-a-glucosides were hydrolyzed much faster than alkyl- $a$-glucosides. The enzyme acts on the maltose derivatives whose reducing groups have been masked. But among glucosylfructoses turanose, maltulose and isomaltulose were attacked with a slow rate while the enzyme was quite inert to sucrose. Malto- and isomalto-oligosaccharides were also hydrolyzed and the enzyme ceased its action at seven to eight units of hexose in both series of oligosaccharides.

The opt. $\mathrm{pH}$ range of Takamaltase was $4.2 \sim 4.6$ and opt. temp., $50 \sim 55^{\circ} \mathrm{C} . \mathrm{Cu}^{++}$and $\mathrm{Hg}^{++}$strongly inhibited the enzyme activity but other metal ions tested had no effects. It is suggested that the enzyme is not a sulfhydryl enzyme because of the lack of effects of SH-reagents on the activity.
\end{abstract}

The authors previously reported on the crystallization of mold maltrase ${ }^{1,2)}$, and it has been shown that the enzyme is a transglucosidase ${ }^{3}$ ) which is believed to be similar to an enzyme described as "transglucosidase" of mold by other workers ${ }^{4,5}$ ).

For maltose-hydrolyzing activity in mold, two enzymes, maltase and saccharogenic amylase, are undoubtedly responsible. From the point of view of $\alpha$-glucosidase activity, saccharogenic amylase has been considered to be quite different from maltase in some points, i.e. the saccharogenic amylase has no activity of transglucosidation action and is inactive to $\alpha$-heteroglucosides. The authors, however, recently found a new type of saccharogenic amylase from Takadiastase which is able to

\footnotetext{
1) S. Sugawara, Y. Nakamura and T. Shimomura, This Journal, 23, 156 (1959).

2) S. Sugawara, Y. Nakamura and T. Shimomura, ibid., 24, 112 (1960)

3) S. Sugawara, Y. Nakamura and T. Shimomura, ibid., 24, 278, $281(1960)$.

4) J.H. Pazur and D. French, J. Biol. Chem., 196, 265 (1952). 5) Y. Tujisaka and J. Fukumoto, Symp. on Enzyme Chem. Japan, 1 0, 84 (1958).
}

hydrolyze the $\alpha$-heteroglucosides ${ }^{6}$. Thus because of the occurrence of such a combined system of $\alpha$-glucosidase activities in mold, the contradictory results on the substrate specificity of mold $\alpha$-glucosidase had been reported by several workers7).

The present paper deals with the specificity of crystalline Takamaltase on various $\alpha$-heteroglucosides and oligosaccharides, and the $\mathrm{pH}$ optima, the temperature dependence and the effects of inhibitors. Recently Matsushima has reported on the substrate specificity of purified Takamaltase freed from amylases ${ }^{8}$ ) and the results were practically identical with the findings described in the present paper.

\section{EXPERIMENTAL RESULTS}

\section{Materials and Methods.}

All the $a$-glucosides were synthesized chemically. Malto- and isomalto-oligosaccharides were prepared by

\footnotetext{
6) S. Sugawara, Y. Nakamura and T. Shimomura, Memoirs Fac. Agriculture of Hokkaido Univ., 3, 96 (1960).

7) c.f. A. Gattschalk, The Enzymes, 1950, p. 551.

8) T. Matsushima, $J$. Biochem., 48, 138 (1960).
} 
partial acid-hydrolysis of potato amylose and dextran according to the method described by Whelan et al. ${ }^{\text {) }}$ and Turvey et al. $^{10}$ ) respectively.

Among the glucosylfructoses, turanose was obtained from commercial source, and maltulose and isomaltulose were prepared by treating the corresponding aldodisaccharides with lime-water at room temperature for $24 \mathrm{hrs}$ and separating the resulting keto-saccharides by carbon-column chromatography.

Preparation of crystalline Takamaltase and assay procedure were reported previously ${ }^{8}$.

Action of the Enzyme on Alkyl- and Aryl-a-glucosides.

Methyl, ethyl, phenyl, $p$-nitrophenyl and $p$-cresol$a$-glucosides were used as substrates. Twenty $\mathrm{ml}$ of $0.01 \mathrm{M}$ substrate sol., $1 \mathrm{ml}$ of $0.1 \mathrm{~m}$ acetate buffer ( $\mathrm{pH}$ 5.0 ) and $0.5 \mathrm{ml}$ of $0.1 \%$ enzyme sol. were mixed and made up to $25 \mathrm{ml}$ with water. The resulting sol. was kept at $40^{\circ} \mathrm{C}$ and $5 \mathrm{ml}$ aliquot of the reaction mixture was pipetted out for analysis. Analytical procedure was reported previously. The rate of hydrolysis was represented as the percentage of decomposition of the substrates.

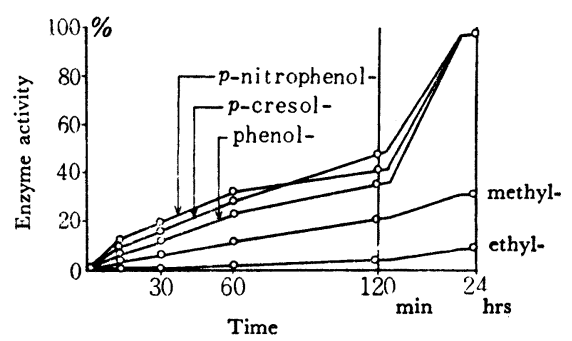

Fig. 1. Action of Crystalline Takamaltase on Alkyl- and Aryl- $\alpha$-glucosides.

As shown in Fig. 1, the $a$-heteroglucosides tested were attacked by this enzyme and the rate of hydrolysis of alkyl- $a$-glucosides were much lower than that of aryl- $a$-glucosides.

Action of the Enzyme on Gluco-disaccharides, Glucosylfructoses, and Malto- and Isomalto-oligosaccharides.

The conditions of the enzyme reaction and the analytical procedure were the same as those described in the section of $a$-heteroglucosides.

As shown in Fig. 2 isomaltose was also hydrolyzed by this enzyme, but the rate of hydrolysis was lower than that of maltose. Trehalose was not hydrolyzed 9) W. J. Whelan, J. M. Bailey and P. J. P. Roberts, J. Chem. Soc., 1953, 1293.

10) J. R. Turvey and W. J. Whelan, Biochem. J., 67, 49 (1957)

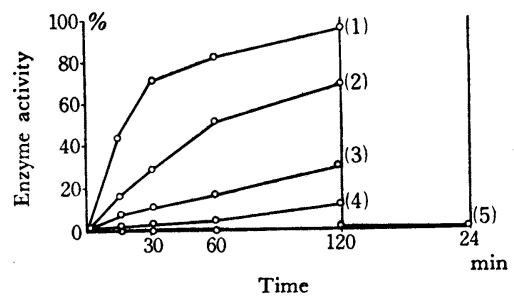

(1) maltose

(2) isomaltose

(3) maltosazone

(4) maltobionic acid

(5) cellulobiose trehalose

hrs

Fig. 2. Action of Crystalline Takamaltase on Gluco-disaccharides and Maltose-derivatives.

while maltosazone and maltobionic acid were attacked at a slow rate (Fig. 2) .

Among glucosylfructoses, the non-reducing sugar sucrose was not hydrolyzed and turanose, maltulose and isomaltulose served as substrates for this enzyme (Fig. 3).

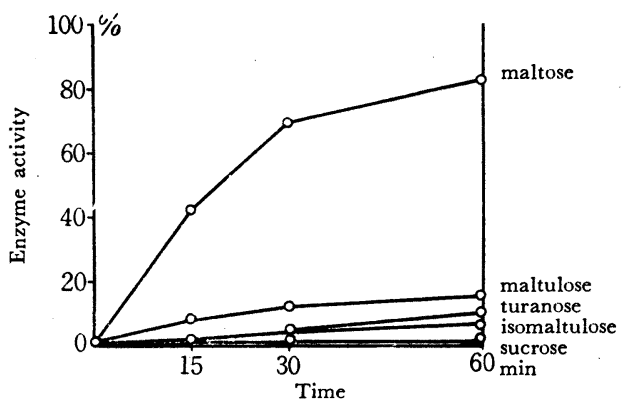

FIG. 3. Action of Crystalline Takamaltase on Glucosylfructoses.

The limiting length of substrate to be attacked by this enzyme as an oligosidase was determined by using malto- and isomalto-oligosaccharides. The data shown in Fig. 4 and Fig. 5 indicated that in both series of oligosaccharides the sugars above seven to eight units of hexose were not hydrolyzed and that the rate of hydrolysis decreased with the increasing degree of polymerization.

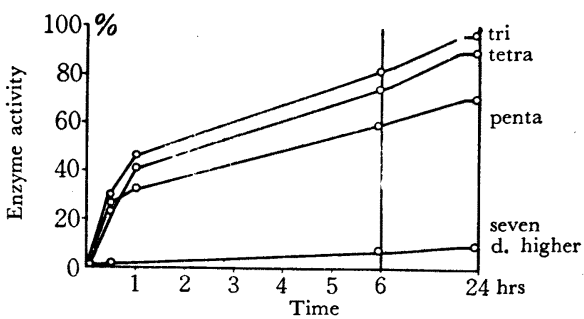

Fig. 4. Action of Crystalline Takamaltase on Malto-oligosaccharides. 


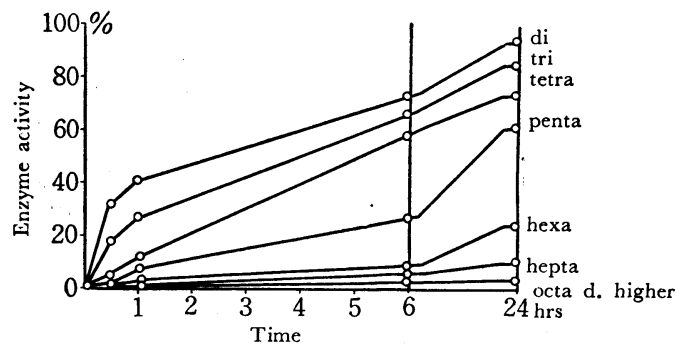

Fig. 5. Action of Crystalline Takamaltase on Isomalto-oligosaccharides.

\section{pH Optimum.}

A mixture of $5 \mathrm{ml}$ of $0.01 \mathrm{M}$ maltose sol., $4 \mathrm{ml}$ of McIlvaine buffer and $1 \mathrm{ml}$ of enzyme sol. was incubated at $40^{\circ} \mathrm{C}$. After $30 \mathrm{~min}$ the percentage of hydrolysis was measured by using $5 \mathrm{ml}$ aliquots of the incubated mixture.

The $\mathrm{pH}$ optimum lay in the range of $\mathrm{pH} 4.2 \sim 4.6$ (Fig. 6).

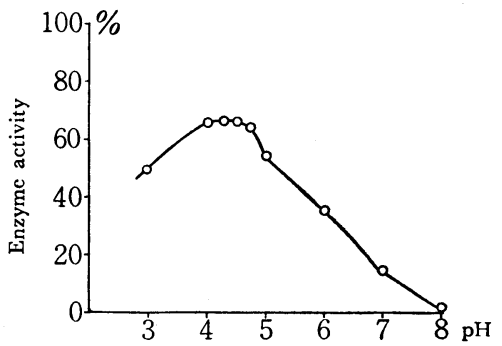

FIG. 6. pH-Activity Curve in Takamaltase Action.

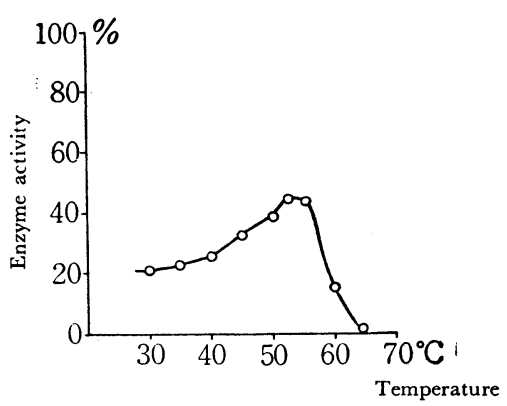

FIG. 7. Temperature-activity Curve in Takamaltase Action.

\section{Temperature Dependence.}

Five $\mathrm{ml}$ of $0.01 \mathrm{M}$ maltose sol., $1 \mathrm{ml}$ of McIlvaine buffer ( $\mathrm{pH} 4.0$ ) and $3 \mathrm{ml}$ of water were mixed and kept for $10 \mathrm{~min}$ at various temperatures. Then $1 \mathrm{ml}$ of enzyme sol. was added and the reaction was run for $20 \mathrm{~min}$.
About $55^{\circ} \mathrm{C}$ was the optimal temperature for the enzyme action.

Effects of Metal Ions and SH-reagents on Crystalline Takamaltase.

Ingredients for reactions to determine the effectiveness of metal ions at a concentration of $10^{-3} \mathrm{M}$ on the enzyme were as follows: $5 \mathrm{ml}$ of $0.01 \mathrm{~m}$ maltose sol., $1 \mathrm{ml}$ of enzyme sol., $2 \mathrm{ml}$ of McIlvaine buffer ( $\mathrm{pH} 4.0$ ) and $1 \mathrm{ml}$ of $0.01 \mathrm{M}$ metal ions, e.g. $\mathrm{HgCl}_{2}, \mathrm{CuSO}_{4} \cdot 5 \mathrm{H}_{2} \mathrm{O}$, $\mathrm{BaCl}_{2} \cdot 2 \mathrm{H}_{2} \mathrm{O}, \quad \mathrm{Pb}$-acetate $2 \mathrm{H}_{2} \mathrm{O}, \quad \mathrm{CaCl}_{2} \cdot 2 \mathrm{H}_{2} \mathrm{O}, \quad \mathrm{MgSO}_{4} \cdot$ $7 \mathrm{H}_{2} \mathrm{O}, \mathrm{ZnSO}_{4} \cdot 7 \mathrm{H}_{2} \mathrm{O}, \mathrm{NiSO}_{4} \cdot 7 \mathrm{H}_{2} \mathrm{O}$ and Co-acetate. After $30 \mathrm{~min}$ incubation at $40^{\circ} \mathrm{C}, 5 \mathrm{ml}$ aliquot was pipetted and the enzyme activity was assayed. In this period of incubation $\mathrm{Hg}^{++}$and $\mathrm{Cu}^{++}$inhibited the enzyme to an extent of $100 \%$ and $80 \%$, respectively. All the other metal ions examined exhibited no effect on the enzyme activity.

Sulfhydryl reagents, e.g. $p$-chloromercuribenzoate and iodoacetate were also examined for the inhibitory action on the enzyme. At $10^{-4}$ and $2 \times 10^{-4} \mathrm{M}$ concentrations of the reagents they had no effect on the activity and glutathione exhibited no accelerating action. The procedure used for determining the effects was the same as that used for the effects of metal ions except the concentrations of the reagents.

Transglucosidation Action of the Enzyme at Various pH's and Temperatures or in the Presence of Metal Ions.

In the course of the experiments on $\mathrm{pH}$ or temperature dependence and on effects of metal ions or SHreagents, the transglucosidase activity of the enzyme was examined along with the hydrolysis activity.

Paperchromatographic observation on oligosaccharides formation showed that the presence of one activity was always accompanied by that of the other.

\section{DISCUSSION}

As stated in the section of introduction in the present paper, the $\alpha$-glucosidase activity in mold is dependent upon a combined system, including maltase and various types of saccharogenic amylases. And a remarkable variation is generally observed in the activity of each enzyme in such a diastic enzyme system.

These facts have led hitherto the contradictory findings on the substrate specificity of mold $\alpha$-glucosidase. Leibowitz classified maltases from various sources into glucosido-type 
(yeast, animal) and gluco-type (mold) ${ }^{11)}$.

The present experiments using crystalline Taka-maltase showed that the enzyme acts upon various $\alpha$-oligosaccharides and $\alpha$-glucosides. These results as well as the difference in the rate of hydrolysis of these substrates lead to a conclusion that Taka-maltase has affinities not only to the glucon moiety, but also to the aglucon moiety of the substrate.

Among $\alpha$-glucosides, the rate of hydrolysis of alkyl- $\alpha$-glucosides was extremely low as compared with that of saccharides or aryl- $\alpha$-glucosides. The size of aglucon moiety of alkyl$\alpha$-glucosides seemed to be related to the enzyme action. This was also observed with aryl- $\alpha$-glucosides.

Among saccharides the enzyme hydrolyzed isomaltose besides maltose and this was also the case with both series of the oligosaccharides, indicating the cleavage of both $\alpha-1,4$ and $\alpha$-1,6 linkages.

The enzyme ceased its action on malto- and isomalto-oligosaccharides at seven eight units of glucose in the molecule. This is one of the most distinct differences between maltase as oligosidase and saccharogenic amylase as polyase. As previously reported ${ }^{2}$, mold maltase acts on maltose and synthesizes many oligosaccharides, either dextran series or panose series of saccharides. The highest polymers of such saccharides formed were dextranheptaose and 4- $\alpha$-[dextranheptaosyl]-D-glucose. It was not clear whether such hepta- and octasaccharides are the limitation of polymerization or not. But now, considering the transgiucosidation reaction being reversible, it is concluded that the highest polymers to be synthesized are hepta- to octasaccharide, as already reported.

Among maltose derivatives maltosazone and maltobionic acid were substrates for this en-

11) J. Leibowiz, Z. Physiol. Chem., 149, 184 (1925). zyme. According to Matsushima ${ }^{8)}$, methyl- $\alpha$ maltoside was hydrolyzed by purified Takamaltase, forming glucose and methyl- $\alpha$-glucoside. Those maltose-derivatives which were masked on their reducing groups seemed to be attacked by this enzyme, but the rate of hydrolysis was very low. Among glucosylfructoses the cleavage of $\alpha$-glucosidic linkage was observed in turanose, maltulose and isomaltulose. The cleavage of $\alpha$-glucosidic linkage in sucrose has been observed only in yeast $\alpha$-glucosidase action.

$\alpha$-Heteroglucosides, and reducing disaccharides and their derivatives were generally attacked by mold maltase. These compounds have a semiacetal linkage in the glucon side and a etheric linkage in the aglucon side of oxygen bridge. On the other hand, in nonreducing disaccharides, which were quite inert to the enzyme, both sides of the oxygen bridge are semiacetal linkages. Such a defference in the mode of linkages would give an explanation, besides $\beta$-configuration, for the substrate specificity of mold maltase.

The optimal $\mathrm{pH}$ range of crystalline Takamaltase was $\mathrm{pH} 4.2 \sim 4.6$ and this was quite different from $\mathrm{pH}$ 3.81) for crystalline maltase isolated from Koji mold. This is probably due to the difference in the strains of $A s p$. oryzae used. But the substrate specificity or transglucosidation action was identical in both enzymes. Takamaltase lost its activity in alkaline side and the heat stability was considerably high. These findings were also practically identical with the maltase from Koji mold.

It is suggested that Takamaltase is not a sulfhydryl enzyme because of the lack of inhibition by sulfhydryl reagents.

Acknowledgement The authors are indebted to Tetuo Sekiguchi for his assistance in carrying out parts of this work. 